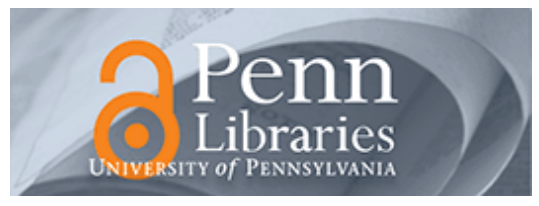

University of Pennsylvania

ScholarlyCommons

Management Papers

Wharton Faculty Research

8-2015

\title{
I Used to Work at Goldman Sachs! How Firms Benefit From Organizational Status in the Market for Human Capital
}

\author{
Matthew J. Bidwell \\ University of Pennsylvania \\ Shinjae Won \\ University of Pennsylvania \\ Roxana Barbulescu \\ McGill University \\ Ethan Mollick \\ University of Pennsylvania
}

Follow this and additional works at: https://repository.upenn.edu/mgmt_papers

Part of the Management Sciences and Quantitative Methods Commons

\section{Recommended Citation}

Bidwell, M. J., Won, S., Barbulescu, R., \& Mollick, E. (2015). I Used to Work at Goldman Sachs! How Firms Benefit From Organizational Status in the Market for Human Capital. Strategic Management Journal, 36 (8), 1164-1173. http://dx.doi.org/10.1002/smj.2272

This paper is posted at ScholarlyCommons. https://repository.upenn.edu/mgmt_papers/206

For more information, please contact repository@pobox.upenn.edu. 


\title{
I Used to Work at Goldman Sachs! How Firms Benefit From Organizational Status in the Market for Human Capital
}

\author{
Abstract \\ How does employer status benefit firms in the market for general human capital? On the one hand, high \\ status employers are better able to attract workers, who value the signal of ability that employment at \\ those firms provides. On the other hand, that same signal can help workers bid up wages and capture the \\ value of employers' status. Exploring this tension, we argue that high status firms are able to hire higher \\ ability workers than other firms, and do not need to pay them the full value of their ability early in the \\ career, but must raise wages more rapidly than other firms as those workers accrue experience. We test \\ our arguments using unique survey data on careers in investment banking. \\ Disciplines \\ Management Sciences and Quantitative Methods
}




\section{USED TO WORK AT GOLDMAN SACHS! HOW FIRMS BENEFIT FROM ORGANIZATIONAL STATUS IN THE MARKET FOR HUMAN CAPITAL}

Matthew Bidwell ${ }^{1}$, Shinjae Won ${ }^{1}$, Roxana Barbulescu ${ }^{2}$, and Ethan Mollick ${ }^{1}$

${ }^{1}$ The Wharton School of the University of Pennsylvania, Philadelphia, Pennsylvania, U.S.A.

${ }^{2}$ McGill University, Montreal, Quebec, Canada.

Matthew Bidwell: Associate professor at the Wharton School mbidwell@wharton.upenn.edu; Shinjae Won: PhD student at the Wharton School wonshinj@ wharton.upenn.edu;

Roxana Barbulescu: Assistant professor at McGill University Roxana.barbulescu@ mcgill.ca; Ethan Mollick: Assistant professor at the Wharton Schoolemollick@ wharton.upenn.edu

\footnotetext{
ABSTRACT

How does employer status benefit firms in the market for general human capital? On the one hand, high status employers are better able to attract workers, who value the signal of ability that employment at those firms provides. On the other hand, that same signal can help workers bid up wages and capture the value of employers' status. Exploring this tension, we argue that high status firms are able to hire higher ability workers than other firms, and do not need to pay them the full value of their ability early in the career, but must raise wages more rapidly than other firms as those workers accrue experience. We test our arguments using unique survey data on careers in investment banking.
} 


\section{INTRODUCTION}

Reflecting the central role that human resources play in every area of firm activity, strategy scholars are paying increasing attention to the role of human capital in allowing firms to achieve competitive advantage (Coff, 1997; Felin, Zenger, and Tomsik, 2009; Wang, He, and Mahoney, 2009). A particular area of debate has been whether firms can gain sustained advantage through better access to general human capital (Campbell, Coff, and Kryscynski, 2012; Chadwick and Dabu, 2009). In theory, some firms could consistently be better able to attract and retain workers than others, allowing them preferential access to a critical resource. They would need to do so, though, in a way that is difficult for others to imitate, and that allows the firms, rather than their workers, to capture the benefits of that labor market access. The law firm Wachtell reportedly gained such an advantage by recruiting Jewish lawyers ignored by other firms (Starbuck, 1993). Scholars have struggled to move beyond this one example, though, to provide generalizable analyses of firms gaining advantage from access to general human capital.

In this paper, we explore whether organizational status in the labor market might serve as such a source of sustained advantage in accessing human capital. Drawing on prior work, we suggest that firms with higher status should have substantial advantages in attracting workers, because workers believe that employment at high status firms signals their own ability, helping them to develop their careers (e.g. "I used to work at Goldman Sachs!"). The positional nature of status, coupled with its persistence, also makes this a source of advantage that is difficult to imitate. Yet that same use of status to signal workers' value can also make it hard for firms to capture the value that status creates: if employment at a high status firm makes workers more attractive to other employers, then those workers should be well placed to bid up their wages.

We develop these arguments to argue that higher status firms do achieve sustainable 
advantage in their access to human capital, but only in the early stages of workers' careers. Analyses of data from a unique career survey of MBA alumni working in the investment banking industry confirm our main arguments. Our results suggest that, given the prevalence and persistence of status in different markets, the attainment of sustainable rents in the market for human capital may be a common phenomenon, rather than a rare event as previously theorized, and can operate as an important source of sustained heterogeneity among organizations.

\section{THEORY AND HYPOTHESES}

The main focus of this paper is on the role of employer status in providing firms with an advantage in the market for human capital. Status is a dimension of social structure that ranks actors according to their relative social position or prestige (Bothner, Podolny, and Smith, 2011; Podolny, 1993; Weber, 1968). An organization's status may vary across different audiences (D’Aveni, 1996); we focus on firms' status among workers, reflecting the respect accorded to them as employers.

Status can create advantage for firms in the market for general human capital because of workers' preference for working in those firms. High status employers are better able to attract workers than their competitors because workers believe that those employers confer a valuable signal of their employability (Phillips, 2001), helping them to secure better jobs in future (Graffin et al., 2008). First, as much research suggests, affiliation with a high status other is frequently used as a signal of quality in markets (e.g. Podolny, 1993; Benjamin and Podolny, 1999). Moreover, being at a high status firm may also lead to better peer-training as workers are surrounded by more able colleagues, and may also help workers to build more valuable social networks. All of these benefits of employment at high status firms then help those firms to hire better employees, creating a virtuous cycle between worker ability and organizational status. 
Hamori (2006) provides evidence of this advantage, showing that workers accept smaller promotions to work in firms that are renowned for operational excellence.

Status is also rare and difficult to imitate, unlike other means by which firms might attract workers, such as better working conditions or more training. Status's positional nature makes it a scarce resource: the higher the position in a status ordering that an actor occupies, the rarer that position is. Status is also persistent, as the benefits accruing to high status actors allow them to maintain their status over time (Benjamin and Podolny, 1999). As a consequence, high status employers should have an enduring advantage over other organizations in attracting workers.

\section{The Challenges of acquiring rents from status}

At the same time that status helps firms attract workers, it also imposes constraints on their ability to benefit from that attractiveness, affecting the form that firms' labor market advantage will take. First, prior research has noted how high status firms are often constrained to act in ways that are consistent with their status (Phillips, Turco, and Zuckerman, 2013). In the labor market, that translates into a constraint on whom they can hire. In principle, firms could exploit their attractiveness to workers in one of two ways: hiring better quality workers at the same wage as their competitors, or hiring the same quality workers at lower wages. Because a high status firm's labor market advantage is based on beliefs about the quality of workers that it hires, hiring lower quality workers could ultimately threaten that advantage. Hence, high status firms are constrained to translate their preferential labor market access into hiring a more highly skilled workforce than their competitors without needing to pay the wages that those skills could command.

Second, the very visibility that creates the advantages of status also makes it difficult for 
firms to benefit from status. Being persistently able to attract higher quality workers than their competitors is not sufficient for high status employers to achieve advantage in the labor market. A further condition is that they are also able to prevent any rents accruing from those advantages from being captured by their workers. Because employment by a higher status firm is valuable as a signal of workers' quality, workers within those firms should also have a higher outside value. Empirical work by Farber and Gibbons (1996) shows that observable signals of worker ability are associated with a constant wage premium throughout workers' careers, as employers bid up workers' wages to their expected productivity. If status affiliation represents a signal of ability, then it should also be associated with wage increases for workers, preventing employers from capturing any benefits from their status.

Because of these challenges, we believe that high status employers are able to benefit from their status, but only under certain conditions. Specifically, high status firms are able to capture some of the value that their status creates at the beginning of workers' careers. Two processes should help firms to capture the rents of their status early in workers' careers. First, adverse selection leads employers to be wary of workers who change jobs, on the basis that such moves might reflect poor performance in their prior job (Gibbons and Katz, 1991; Greenwald, 1986). Acemoglu and Pischke (1998) suggest that such labor market frictions allow firms to benefit from training their workers in general skills: since other prospective employers are suspicious of workers who try to move firms, it is hard for incumbents to bid up their wages to reflect their new productivity. Similarly those workers who enter high status firms cannot credibly threaten to leave instantly in order to benefit from their newfound signal of quality. Instead, they must establish a track record at the high status firm, achieving some seniority and ratifying the initial judgment of the high status organization to hire them, before they will be 
attractive elsewhere. There may also be particular advantages to having received promotions to a higher level within those organizations, since promotions tend to act as signals of ability (Trevor, Gerhart, and Boudreau, 1997). Since workers at higher status firms are believed to be more able, those that win promotions within those firms may be seen as particularly talented, further elevating their value in the labor market.

Second, workers are likely to place a much higher value on affiliation with a high status firm at the beginning of their career. How workers value different rewards varies over the course of their careers (Cherrington, Condie, and England, 1979; Tolbert and Moen, 1998). Early in their careers, workers most value jobs that help them to develop the resources that they need to advance their careers, such as opportunites to develop skills or signal their ability (Bidwell and Briscoe, 2010). It is also at the beginning of the career that workers are least likely to have other resources that could substitute for status affiliation in signaling ability.

In these early career jobs, we therefore expect that high status firms are able to recruit better workers than their lower status rivals, but are not required to pay them wages commensurate with their quality. Instead, those workers join the high status firms in order to acquire a signal of their ability. Despite hiring higher quality workers than other firms, as we theorized above, we therefore predict that:

H1: Higher status firms offer pay that is not different from lower status firms for workers at the start of their career.

The corollary to this argument is that workers will no longer place the same value on their affiliation with a high status employer once they have advanced in their careers. Having established a track record through their achievements, a high status affiliation is less critical to them as a signal of their ability. Having established themselves, they also receive less of a 
penalty for moving firms.

As a consequence, we would not expect high status firms to be able to hold down wages for more experienced workers. Instead, later in their career, workers should be paid the full value created by their ability. This implies that workers' wages should grow more rapidly with seniority in high status firms. Because the workers hired by high status firms tend to be more able, we would generally expect them to be paid more throughout their careers, reflecting their greater value to the firm. More senior workers in higher status firms can therefore demand wages commensurate with their ability, leading wages in those firms to rise faster than they do in lower status firms. We therefore predict that:

H2: Higher status firms offer pay that is higher than lower status firms as workers increase in rank and experience over their career, so that pay increases more with rank and experience at high status firms than low status firms.

\section{METHODS}

We tested these hypotheses within the investment banking industry. This industry has been used in several studies of status because of its very clear status hierarchy (Podolny, 1993, 1994). The extensive inter-firm mobility of its workers (Groysberg, 2010) also raises the value of employer status in this context, making it well suited to testing our arguments.

\section{Measuring employer status}

Our main independent variable, employer status, is derived from the prestige ranking published by Vault.com, a website that provides career-related information for recruiters and job seekers. Vault compiles its annual prestige ranking by sending out surveys to professionals in the industry and asking them to rate the prestige of the firms that they are familiar with (excluding the firm where they work) on a scale of 1 to 10 . The average of the scores is calculated, and the firms are 
ranked accordingly, from 1 (the most prestigious) to 50 (least prestigious). These prestige rankings are a particularly good measure of status because they are rooted in peer attributions and represent a combination of social and economic factors. The rankings also focus specifically on the employment aspects of status, consistent with our theory.

We gathered data on rankings from 2001 (when the prestige survey began) to 2009. The ranks were then reversed by calculating the difference between each rank and 50, so that increases in the status variable correspond to increases in organizational status. Exploratory analyses found a very high degree of persistence in employer status, consistent with much other research (e.g. Benjamin and Podolny, 1999; Merton, 1968). For example, of the 10 highest status firms in 2003 (the first year that 50 banks were included in the rating), 7 were still in the top 10 in 2009. The only firms to drop out of the top 10 were either bought by other firms or were no longer primarily involved in investment banking.

The persistent nature of status led us to assign each firm a single measure of status across all years in the sample, rather than allowing the firm's status to vary over time. We believed that using a time varying measure would likely introduce more measurement error than meaningful variation into our data. Specifically, each bank's status is measured as the highest ranking that the bank achieved between 2001 and 2009. This approach helps to deal with years when the firm does not appear in the data. The results were robust across different aggregations of Vault rankings, such as an average of rankings across 2001-2009, and a dichotomous variable for banks that ever appeared in the list of top ten banks.

\section{Other variables}

We tested how firms' status relates to the wages that they pay using data from a survey of MBA alumni from a large US business school, collected during the summer of 2011. This dataset 
allows us to construct a sample of largely similar individuals, from the same school and with the same qualification, working at different organizations within the same industry.

For this study we draw on data from alumni who graduated after 1990 (response rates from older cohorts were low, increasing concerns about non-response bias). Among that population, we received responses with usable information from around 32 percent of the students whom we could contact, and complete responses from around 23 percent. To check for response biases, we compared respondents with the LinkedIn resumes of non-respondents using a subsample of 2,172 alumni. We found no evidence of systematic response biases in the financial industry: the response rate of alumni identified in LinkedIn as being in financial services industry was within two percent of the overall response rate to the survey. Similarly, the job level of surveyed employees did not reflect any systemic response bias.

We asked the alumni about each employer that they had worked for and also about each job that they had held within that employer. ${ }^{1}$ Our analyses use a subset of 458 individuals who held at least one job in the investment banking industry since 2000 (we only consider job spells after that date because of restrictions on our status data), with 911 person-job observations. Among these, we were able to identify 725 person-job observations with job titles that were usable for our analyses (explained below under rank), and whose employer is part of Vault's ranking. We also dropped 203 jobs (106 unique persons) outside the United States because reported pay may be in currency other than US dollars. An additional 13 person-job observations with missing pay data were excluded from the analysis. The final dataset consisted of 509 person-job observations.

\footnotetext{
${ }^{1}$ We defined a move across jobs as 'a significant promotion to a new title or rank in the organization that involved significant changes to your job tasks, number of people managed, or compensation. A job change is also a substantial change in the nature of the work that you performed, usually accompanied by a change in title or a move to a different organizational unit.'
} 
Pay. We test how pay varies across firms based on respondents' self-reports of their approximate annual earnings in their first year in each of the job spells that we reported. Because of the skewed nature of the pay variable, we use natural logarithms.

Job rank. We also calculated a job rank for each job, referring to the vertical location of a job of the organizational hierarchy. The survey asked respondents about their title within each job that they held. We then coded these titles to create a consistent rank across the various different jobs. Interviews suggested that the progression of job ranks was often similar across investment banks, allowing for the creation of a consistent set of titles. Because the data consists of post-MBA jobs, the lowest rank the graduates are hired into is the associate-level position. Assigning a numerical value of 1 to the associates and 9 to senior executives, the variable rank ranges from 1 (low) to 8 (high) in our final sample. We also surveyed current students about the titles in their former employers, allowing us to tailor our coding for some of the largest banks in our sample (which together made up 80 percent of the jobs in our sample). ${ }^{2} \mathrm{We}$ validated the hierarchy by regressing pay on rank. We found that pay increased monotonically with rank, and that controlling for rank on top of year increased the $\mathrm{R}^{2}$ from 8.05 percent to 41.79 percent.

Table 1 includes descriptive statistics for our variables.

\section{RESULTS}

Ability of new hires. Before testing our main hypothesis, we sought to validate our baseline assumption that higher status firms hire higher quality workers than lower status firms.

Specifically, we examined whether workers who won academic awards were more likely to work for higher status employers in their first job (prior work shows that grades correlate with future

${ }^{2}$ Where we found companies adopting idiosyncratic titles, we matched those to this scheme. Job titles that could not be strictly matched to these five categories, but appeared to be in between these existing categories were given values in between these ranks. For example, senior associates were assigned a value of 2 , and senior vice presidents were assigned a value of 4 unless other evidence suggested that they were more senior than this. 
performance, conscientiousness and intelligence (Roth et al., 1996; Lounsbury et al., 2003)). In analyses not reported here, we found that those students who had won more awards or graduated with honors took jobs at higher status firms, supporting our argument that higher status firms recruit higher ability workers.

Determinants of pay. Table 2 presents our analyses of respondents' pay. Our unit of analysis is the individual job. We control for year, age, gender, year of MBA graduation, tenure at the beginning of the job, and whether the respondent graduated from the executive MBA program. We also control for the rank of the job, in case workers in higher status firms are promoted more rapidly because of their higher quality. Errors are clustered by employer to take account of nonindependence of within-firm observations.

Our models support our hypotheses that starting pay does not differ significantly between high and low status firms early in the career of individuals, but that there is a significant difference among more senior employees. Models 2 through 4 present interactions between status and rank, age and experience. In each case, the interaction is significant, indicating that pay rises more quickly in high status firms, as predicted by H2. Moreover, close inspection of the coefficients supports our argument in $\mathrm{H} 1$ that initial pay is no higher in high status firms than low status firms. The estimated effect of one unit of status on $\log$ of pay when rank is 1 equals 0.0028 , when age is 30 it equals -0.0135 , and when post MBA experience is 0 it equals -0.0029 . In each case, the coefficients are negative but insignificant. We are only able to see a significantly positive effect of status on pay among senior workers. For example, an employer whose status is ten units higher (e.g., Goldman Sachs vs. Vanguard) pays about 15 percent more for employees at VP level. These effects of the interaction are illustrated in Figure 1. In Figure 2, we also plot out the estimated coefficients for each rank, based on estimates using rank dummies 
(we dropped the 4 individuals in rank 8 because of concerns about how their jobs were classified).

\section{Alternative explanations}

We also performed additional analyses to explore alternative explanations for our results. First, we examined whether higher status firms might also offer more opportunities for internal advancement, perhaps because they engaged in less lateral hiring. In analyses not reported here, we used Cox hazard rate analysis to estimate whether the rate of promotion into higher level jobs was any greater in higher status firms than lower status firms. We found no such effect.

Second, we explored whether higher status firms might have higher ratios of junior to senior workers, making the senior workers more productive and potentially raising their wages. One of the questions in our survey asked respondents about the number of people that they managed in their jobs. We regressed the number of subordinates on job and worker characteristics, and organizational status (results available from the authors). We did not find differences in the ratio of junior to senior workers across firms of different status.

We also further explored the reasons that workers do not immediately leverage the signal of employment at a high status organization into a better offer elsewhere. We examined how the benefits that workers received from status, in terms of entry into higher ranked jobs subsequently, depended on when they moved. In analysis not reported here, we found that the benefits of coming from a higher status firm accrued only to those who had been at the firm for more than 5 years, consistent with our arguments about the difficulties of instantly leveraging employer status into higher pay.

\section{Supplementary analyses: workers' preferences for jobs with high status employers Our}

arguments rest on the idea that workers are attracted to high status firms because of the expected 
career benefits of their status affiliation. We sought to confirm this assumption using an online survey of MBA students from the same school as was used in the alumni survey, who had recently engaged in job search. We surveyed both first and second year students, asking about both internship offers and full time offers; supplementary analyses indicated no significant difference in the responses of the first and second year students. We received a total of 280 completed surveys with a 45.5 percent response rate.

We found that students who were applying to investment banks consistently rated the extent to which the firm's reputation would help with future employability as the most important factor shaping their decisions. ${ }^{3}$ We also conducted conditional logit analyses to explore which factors had most affected decisions to accept a particular offer (we first corrected those scores for bias towards those jobs they had selected - further information on this procedure is available from the authors). Those analyses demonstrated that respondents were indeed more likely to choose those jobs for which they believed that the firm's reputation would help with their future employability. For job seekers in investment banking, the respondents' odds of accepting an offer almost doubled with a one unit increase in their perception of firm's reputation (odds ratio $=1.98$ ). We also found that workers were more likely to accept jobs that offered more prospects for internal advancement and opportunities to develop skills. These findings underline the importance of enhancing future career prospects for early-career workers.

\section{DISCUSSION}

Prior research has suggested that it is difficult for firms to attain rents in the market for general

${ }^{3}$ Respondents were asked to rate each job offer along nine dimensions, given as: (1) pay offered by the firm, (2) likely work-life balance, (3) formal training and mentoring programs, (4) opportunity to develop new skills, (5) interesting work, (6) fit with the culture of the organization, (7) opportunities for advancement within that firm, (8) firm's reputation would enhance future employability, and (9) firm's reputation will help me to advance my future career. We used the last two items to measure the value of high status employers to workers (Cronbach's $\alpha=$ 0.94). 
human capital (Chadwick and Dabu, 2009; Campbell, Coff, and Kryscynski, 2012), and scholars have struggled to come up with generalizable examples of firms achieving such advantage; we propose that employer status could provide firms with such preferential access to human capital, given its value to workers as a signal of their ability and its persistent, hard to imitate nature. At the same time, we note that the publicly observable nature of employer status can make it difficult for firms to capture the benefits that it confers. As a consequence, we propose that having high status will allow firms to hire more able workers without paying them more early in their careers. As workers gain experience, though, even high status firms must pay them the wages that their ability commands. Hence, while employer status provides a real source of advantage in the labor market, those benefits are also bounded by its characteristics as a publicly observable signal.

Such an ability to generate rents from general human capital contrasts with the creation of rents from firm-specific human capital that has often been the focus of prior work (e.g. Hatch and Dyer, 2004; Wang, He, and Mahoney, 2009). Unlike firms that create rents through firmspecific human capital, high status firms generate rents because of the advantages that they confer on workers once those workers leave. Hence, while those firms may want to limit the exit of valued employees ex post, their ability to continue attracting the best workers despite paying them no more than competitors relies on their ability to offer attractive exit options ex ante. This also highlights the potential benefits that firms can gain from workers' agency (cf. Coff, 1997). Other inputs to the firm generally have little preference about which organization uses them. Oil wells don't seek to be owned by a particular firm that might enhance their future value. But workers do care about exactly this issue, allowing firms to benefit from boosting workers' future opportunities. 
An important implication of this paper, therefore, is the value of attending to workers' career needs in competing in the labor market. Indeed, our supplemental analyses indicated that ability to enhance future employability was the most important factor that workers considered in choosing employers in investment banking. Our results therefore indicate that employers should pay close attention to how they can offer to advance workers' careers if they wish to be competitive in the labor market. They also highlight the way that different rewards are important at different career stages, as high status firms that can hold down the wages of their high quality workers early in their careers cannot do so subsequently. It is also possible that firms could build on their advantage further by carefully tailoring their human resource systems to the career stage of their workers. Professional service firms generally exploit workers' career needs to create value, as their business models tend to involve hiring large numbers of junior workers who exchange the valuable training that they receive for wages that are far lower than the rates that clients are billed (Maister, 1997). High status firms might gain even more advantage by hiring larger numbers of junior workers, where they have the most advantage. We did not find evidence of such behavior in this case though.

In addition to elucidating some of the sources of rents in the market for human capital, our study also contributes to the status literature. First, our analyses add to the nascent literature on the role of organizational status on employment (D'Aveni, 1996; Graffin et al., 2008; Phillips, 2001; Rider and Tan, 2011), rather than the more commonly studied markets for goods and services (Podolny, 1993, 2005, p. 76). Prior work has generally focused on understanding how status shapes which organizations workers can move across, or the effects of status on promotion rates. We show how the salient features of status work to mutually benefit both high status employers and high ability employees, providing preferential labor market access to the former 
and a valuable signal of ability for the latter.

Our study also explores a question which has previously received little attention, which is how the benefits of status evolve over time. Although it is well established that high status actors receive better terms of trade in their interactions, reflecting the value that their status confers on partners (e.g. Hsu, 2004; Castellucci and Ertug, 2010), scholars have not explored how those terms evolve over time. Within the labor market, at least, we suggest that the value of a status affiliation declines over time as actors are able to signal their quality independent of their partner. Further research could explore whether similar dynamics play out in other markets.

Our study draws on data from a single industry and it is important that future work extend our analysis to other settings. Other work could also explore in more detail how much the career benefits of working at a high status firm are due to the signal of ability that it provides versus the superior knowledge or more valuable relationships that workers gain from working at a more prestigious firm. Our theory does not directly depend on which of these advantages is more important: our arguments hinge on the idea that working at a high status employer helps workers get better jobs subsequently, not on the exact sources of that advantage.

Nor does our study explore the cost of achieving and maintaining status, focusing instead on the idea that status, once established, endows firms with a certain kind of benefit in the labor market. Previous studies, however, have described some of the costs incurred by high status firms, such as sacrificing potential profits from entering areas of business that are not consistent with their status (Abbott, 1981; Sandefur, 2001; Phillips and Zuckerman, 2001). We have suggested that the need to maintain their status may prevent high status firms from lowering their wages well below market, given their need to attract high ability workers. There may be other important ways in which status constrains these firms' activities. For example, high status firms 
may be more reluctant to recruit from non-traditional sources if such a strategy is seen as inconsistent with their status or challenges the reputation of their employees. These tradeoffs related to organizational status call for deeper investigation of the net value of status as a composite of the benefits and costs in the different markets in which the firms operate.

Also, while we drew on the idea that status is persistent and self-reinforcing, this selfreinforcing process must originate somewhere, possibly from the product market. Such a correlation between product market status and status as an employer suggests the potential for interesting spillovers across markets: as firms are able to attain superior performance in a product market, they may go on to receive competitive advantage in the labor market too. To the extent that their advantage in the labor market is largely due to their status, and that status is a very persistent attribute, it is possible that the resulting labor market advantage could be far more enduring than the initial product market advantage that first spurred it.

\section{ACKNOWLEDGMENTS}

We thank Peter Cappelli, Olivier Chatain, Emilie Feldman, Vit Henisz, Lori Rosenkopf, Ezra Zuckerman, co-editor Will Mitchell, the two anonymous reviewers, and participants of 2012 Strategic Management Society Meeting, 2012 European Group for Organizational Studies Colloquium, and 2013 Academy of Management Meeting for their helpful comments. The study was partially funded by a Sloan Industry Studies Fellowship awarded to the first author and by the Dorinda and Mark Winkelman Distinguished Scholar award, as well as grants from the Wharton Leadership Center and the Wharton Dean's Research Fund. The first two authors contributed equally and are listed alphabetically. The third and fourth authors also contributed equally and are listed alphabetically.

\section{REFERENCES}


Abbott A. 1981. Status and status strain in the professions. American Journal of Sociology 86(4): 819-835.

Acemoglu D, Pischke JS. 1998. Why do firms train? Theory and evidence. Quarterly Journal of Economics 113(1): 79-119.

Benjamin BA, Podolny JM. 1999. Status, Quality, and Social Order in the California Wine Industry. Administrative Science Quarterly 44(3): 563-589.

Bidwell MJ, Briscoe FS. 2010. The Dynamics of Interorganizational Careers. Organization Science 21(5): 10341053.

Bothner MS, Podolny JM, Smith EB. 2011. Organizing Contests for Status: The Matthew Effect vs. the Mark Effect. Management Science 57(3): 439-457.

Campbell BA, Coff R, Kryscynski D. 2012. Rethinking Sustained Advantage from Human Capital. Academy of Management Review 37(3): 376-395.

Castellucci F, Ertug G. 2010. What's in it for them? Advantages of higher-status partners in exchange relationships. Academy of Management Journal 53(1):149-166.

Chadwick C, Dabu A. 2009. Human Resources, Human Resource Management, and the Competitive Advantage of Firms: Toward a More Comprehensive Model of Causal Linkages. Organization Science 20(1): 253-272.

Cherrington DJ, Condie SJ, England JL. 1979. Age and Work Values. The Academy of Management Journal 22(3): 617-623.

Coff RW. 1997. Human Assets and Management Dilemmas: Coping with Hazards on the Road to Resource-Based Theory. The Academy of Management Review 22(2): 374-402.

D'Aveni RA. 1996. A Multiple-Constituency, Status-Based Approach to Interorganizational Mobility of Faculty and Input-Output Competition among Top Business Schools. Organization Science 7(2): 166-189.

Farber HS, Gibbons R. 1996. Learning and wage dynamics. Quarterly Journal of Economics 111(4): 1007-1047.

Felin T, Zenger TR, Tomsik J. 2009. The knowledge economy: emerging organizational forms, missing microfoundations, and key considerations for managing human capital. Human Resource Management 48(4): 555-570.

Gibbons R, Katz LF. 1991. Layoffs and Lemons. Journal of Labor Economics 9(4): 351-380.

Graffin SD, Wade JB, Porac JF, McNamee RC. 2008. The Impact of CEO Status Diffusion on the Economic Outcomes of Other Senior Managers. Organization Science 19(3): 457-474.

Greenwald, BC. 1986. Adverse Selection in the Labour Market. The Review of Economic Studies 53(3): $325-347$.

Groysberg B. 2010. Chasing Stars: The myth of talent and the portability of performance. Princeton University Press: Princeton, NJ.

Hamori M. 2006. Executive career advancement in career moves across employers: the role of organization-level predictors. International Journal of Human Resource Management 17(6): 1129-1151.

Hatch NW, Dyer JH. 2004. Human capital and learning as a source of sustainable competitive advantage. Strategic Management Journal 25(12): 1155-1178.

Hsu DH. 2004. What Do Entrepreneurs Pay for Venture Capital Affiliation? The Journal of Finance 59(4): 18051844.

Lounsbury JW, Sundstrom E, Loveland JM, Gibson LW. 2003. Intelligence, "Big Five" personality traits, and work drive as predictors of course grade. Personality and Individual Differences 35(6): 1231-1239.

Maister DH. 1997. Managing the Professional Service Firm: Free Press.

Merton RK. 1968. The Matthew Effect in Science. Science 159(3810): 56-63.

Phillips DJ. 2001. The Promotion Paradox: Organizational Mortality and Employee Promotion Chances in Silicon Valley Law Firms, 1946-1996. The American Journal of Sociology 106(4): 1058-1098.

Phillips DJ, Turco CJ, Zuckerman EW. 2013. Betrayal as Market Barrier: Identity-Based Limits to Diversification among High-Status Corporate Law Firms. American Journal of Sociology 118(4): 1023-1054.

Phillips DJ, Zuckerman EW. 2001. Middle-Status Conformity: Theoretical Restatement and Empirical Demonstration in Two Markets. American Journal of Sociology 107(2): 379-429.

Podolny JM. 1993. A Status-Based Model of Market Competition. American Journal of Sociology 98(4): 829-872.

Podolny JM. 1994. Market Uncertainty and the Social Character of Economic Exchange. Administrative Science Quarterly 39(3): 458-483.

Podolny JM. 2005. Status signals. Princeton, NJ: Princeton University Press.

Rider CI, Tan D. 2011. Organizational status hierarchies and individual mobility among large US law firms. Paper presented at the Academy of Management, San Antonio.

Roth PL, BeVier CA, Switzer Iii FS, Schippmann JS. 1996. Meta-analyzing the relationship between grades and job 
performance. Journal of Applied Psychology 81(5): 548-556.

Sandefur RL. 2001. Work and honor in the law: Prestige and the division of lawyer's labor. American Sociological Review 66(3):382-403

Starbuck W. 1993. Keeping a butterfly and an elephant in a house of cards: The elements of exceptional success. Journal of Management Studies 30(6): 885-921.

Tolbert PS, Moen P. 1998. Men's and women's definitions of "good" jobs - Similarities and differences by age and across time. Work and Occupations 25(2): 168-194.

Trevor CO, Gerhart B, Boudreau JW. 1997. Voluntary turnover and job performance: curvilinearity and the moderating influences of salary growth and promotions. Journal of Applied Psychology 82(1): 44-61.

Wang HC, He J, Mahoney JT. 2009. Firm-Specific Knowledge Resources and Competitive Advantage: The Roles of Economic- and Relationship-Based Employee Governance Mechanisms. Strategic Management Journal 30(12): 1265-1285.

Weber M. 1968. Economy and Society: an outline of interpretive sociology. Bedminster Press: New York. 
Table 1. Descriptive statistics ( $\mathrm{N}=509)$

\begin{tabular}{|c|c|c|c|c|c|c|c|c|c|c|c|}
\hline & & Mean & S.D. & 1 & 2 & 3 & 4 & 5 & 6 & 7 & 8 \\
\hline 1 & Job rank & 2.69 & 1.91 & 1.00 & & & & & & & \\
\hline 2 & Age & 32.81 & 4.23 & 0.72 & 1.00 & & & & & & \\
\hline 3 & Tenure (day) & 640.66 & 972.55 & 0.65 & 0.48 & 1.00 & & & & & \\
\hline 4 & Female & 0.32 & 0.47 & -0.07 & -0.13 & -0.02 & 1.00 & & & & \\
\hline 5 & Year & 2005.55 & 3.32 & 0.23 & 0.35 & 0.16 & -0.10 & 1.00 & & & \\
\hline 6 & Log of current pay & 12.57 & 0.83 & 0.62 & 0.44 & 0.49 & -0.12 & 0.20 & 1.00 & & \\
\hline 7 & Current employer status & 41.22 & 9.49 & 0.00 & -0.05 & 0.19 & 0.00 & -0.05 & 0.09 & 1.00 & \\
\hline 8 & Time since MBA (year) & 3.49 & 3.81 & 0.85 & 0.58 & 0.61 & -0.02 & 0.27 & 0.60 & -0.03 & 1.00 \\
\hline 9 & Executive MBA & 0.04 & 0.19 & 0.14 & 0.12 & -0.02 & -0.05 & 0.10 & 0.07 & -0.01 & 0.05 \\
\hline
\end{tabular}

Table 2. The effect of employer status on log of current pay: OLS regression

\begin{tabular}{lcccc}
\hline & \multicolumn{4}{c}{$\log (\mathrm{pay})$} \\
\cline { 2 - 5 } & $-0.182^{* *}$ & $-0.171^{* *}$ & $-0.184^{* *}$ & $-0.178^{* *}$ \\
\hline Female & $(0.0539)$ & $(0.0509)$ & $(0.0543)$ & $(0.0521)$ \\
Age & $-0.0418^{* *}$ & $-0.0412^{* *}$ & $-0.143^{* *}$ & $-0.0418^{* *}$ \\
& $(0.0132)$ & $(0.0131)$ & $(0.0314)$ & $(0.0127)$ \\
Job rank & $0.136^{* *}$ & -0.142 & $0.143^{* *}$ & $0.141^{* *}$ \\
Tenure & $(0.0504)$ & $(0.140)$ & $(0.0502)$ & $(0.0511)$ \\
& $0.000103+$ & $3.06 \mathrm{e}-05$ & $5.91 \mathrm{e}-05$ & $4.34 \mathrm{e}-05$ \\
Executive MBA & $(5.82 \mathrm{e}-05)$ & $(6.69 \mathrm{e}-05)$ & $(5.69 \mathrm{e}-05)$ & $(6.03 \mathrm{e}-05)$ \\
& 0.243 & 0.183 & 0.233 & 0.200 \\
Current employer status & $(0.191)$ & $(0.199)$ & $(0.199)$ & $(0.197)$ \\
Current employer status X job rank & 0.00607 & $-0.0126+$ & $-0.0731^{* *}$ & -0.00443 \\
& $(0.00410)$ & $(0.00637)$ & $(0.0237)$ & $(0.00389)$ \\
Current employer status X age & & $0.00731^{*}$ & & \\
Current employer status X time & & $(0.00311)$ & & \\
since MBA & & & $0.00243 * *$ & \\
Constant & & & $(0.000784)$ & \\
& & & & $0.00320^{* *}$ \\
Observations & & & & $(0.00118)$ \\
R-squared & & & & \\
\hline
\end{tabular}

$* * \mathrm{p}<0.01, * \mathrm{p}<0.05,+\mathrm{p}<0.1$ (Robust standard errors in parentheses.)

Unit of analysis is the job. Errors clustered by current employer to account for non-independence of observations. The model additionally controls for year and year of MBA graduation. 


\section{Figure 1. The effect of hierarchical job rank on pay by firm status}

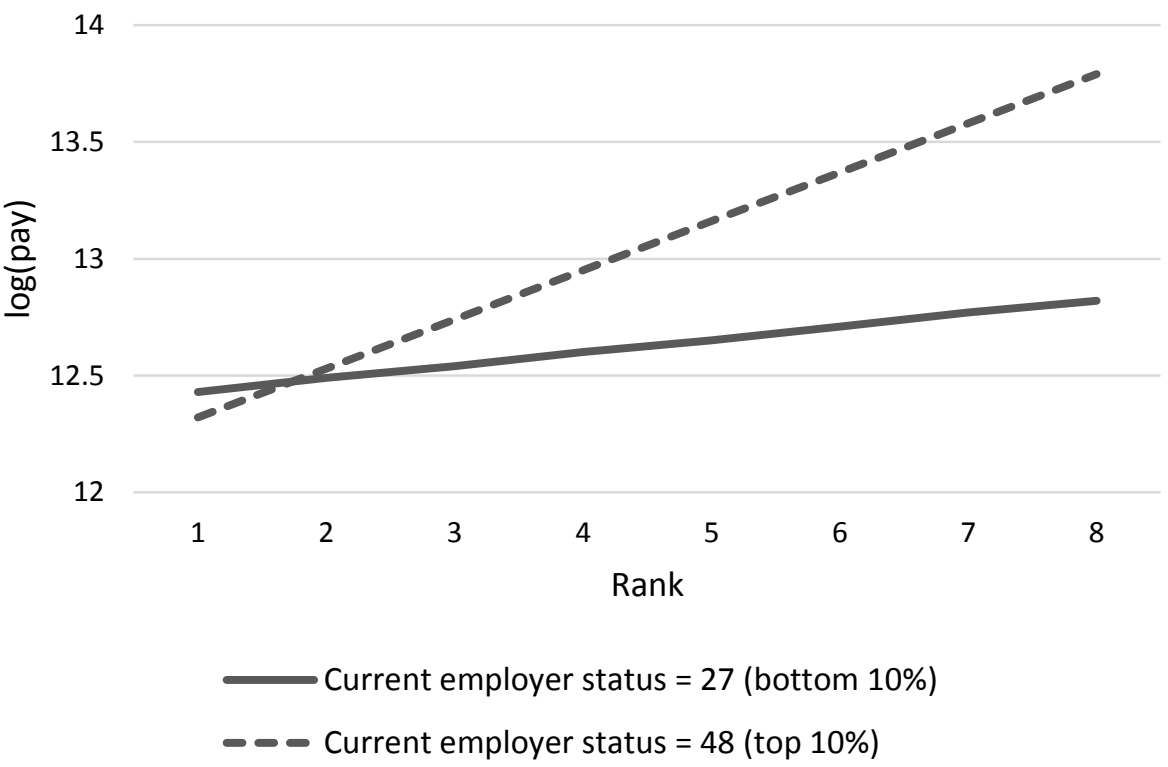

Figure 2. The marginal effect of status on pay*

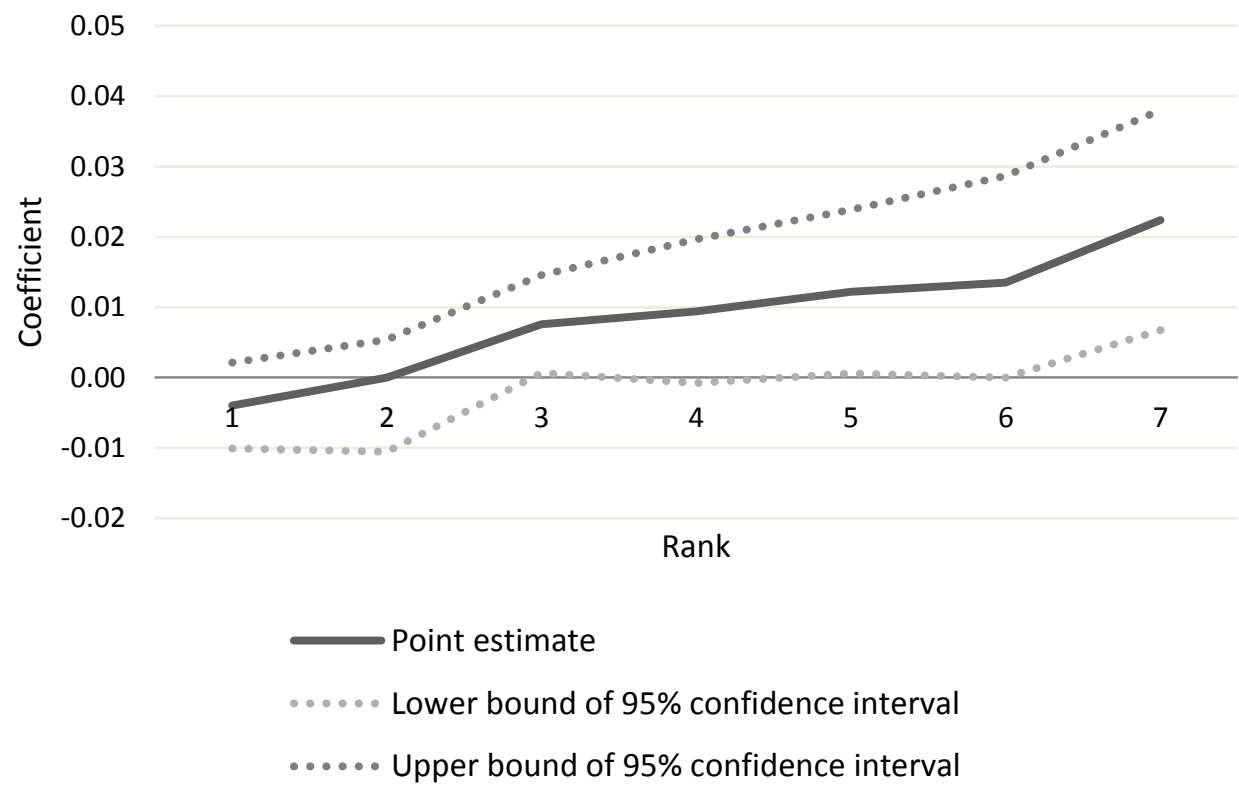

$*$ Rank $=8$ dropped from graph because of difficulties classifying the 4 jobs at that rank. 